\title{
REVIEW : AKTIVITAS ANTIHIPERGLIKEMIK DAN HIPOLIPIDEMIK EKSTRAK PEPAYA (Carica papaya Linn .)TERHADAP TIKUS DIABETES YANG DI INDUKSI OLEH ALOKSAN
}

\author{
Sukmawati, Yasmiwar Susilawati, Tiana Milanda \\ sukmawati17001@ mail.unpad.ac.id \\ Fakultas Farmasi Universitas Padjadjaran \\ J1. Raya Bandung Sumedang Km. 21 Jatinangor 45363
}

\begin{abstract}
Abstrak
Diabetes melitus adalah gangguan metabolisme pada tubuh disebabkan karena sekresi insulin, kerja insulin atau keduanya, yang ditandai dengan gangguan metabolisme karbohidrat, lemak, dan protein. Salah satu tumbuhan obat yang memiliki aktivitas antihiperglikemikdan hipolipidemik adalah pepaya(CaricapapayaLinn).Dari hasil review beberapa artikel diketahui bahwa ekstrak air biji pepaya. ekstrak air daun pepaya dan ekstrak metanol kulit batang pepaya menunjukkan adanya aktivitas antihiperglikemik dan hipolipidemik. Waktu penelitian bervariasi selama 21 dan 30 hari, menggunakan tikus yang diinduksi oleh aloksan. Dosis efektif sebagai antihiperglikemik dan hipolipidemik pada pengujian ekstrak air biji pepaya dan ekstrak daun pepaya adalah $400 \mathrm{mg} / \mathrm{kg} \mathrm{BB}$, sedangkan dosis efektif pada ekstrak metanol kulit batang pepaya adalah $500 \mathrm{mg} / \mathrm{kg} \mathrm{BB}$.
\end{abstract}

Kata kunci :Caricapapaya, antihiperglikemik, hipolipidemik

\section{Pendahuluan}

Diabetes adalah penyakit yang dianggap sebagai salah satu masalah kesehatan utama didunia ${ }^{[1]}$. Diabetes adalah gangguan pada metabolismetubuh yang ditandai dengan gangguan metabolisme karbohidrat, lemak, dan protein yang disebabkan karena gangguan sekresisekresi insulin, insufiensi kerja insulin atau keduanya $^{[2]}$. Di India terdapat sekitar 150 tanaman dari berbagai familia yang beraktivitas antihiperglikemik, dan lebih dari 1200 spesies tanaman yang di gunakan pada terapi diabetes ${ }^{[3]}$. Komplikasi diabetes melitus umumya menyebabkan tingginya kematian, hal ini dapat dicegah dengan penggunaan obat tradisional menggunakan tanaman obat yang memiliki aktivitas antihiperglikemik dan hipolipidemik ${ }^{[3]}$.

Carica papaya Linn.(Caricaceae) adalah pohon tropis yang berasal dari daerah tropis Amerika tetapi sekarang banyak dibudidayakan didaerah tropis lainnya di dunia ${ }^{[4]}$ Buah pepaya dapat dikonsumsi seperti buah melon, yang tersedia sepanjang tahun ${ }^{[5]}$. Pohon Carica papaya Linn. adalah pohon tegak yang tumbuh cepat setinggi 7-8 $\mathrm{m}$ dengan lateks dan batang berdiameter sekitar $20 \mathrm{~cm}^{[2]}$. Daunnya lunak, berlobus, bergerombol di dekat bagian atas tanaman, panjang berukuran hingga $80 \mathrm{~cm}^{[6,7]}$. Buah berwarna kekuningan hingga oranye, bentuk panjang hingga hampir bulat, sekitar $7,5 \mathrm{~cm}-45 \mathrm{~cm}$, dengan tebal daging $2,5-5 \mathrm{~cm}$, rasa manis dan berair ${ }^{[5]}$.

Buah pepaya kaya akan vitamin A dan $\mathrm{C}^{[8]}$. Studi fitokimia menunjukan bahwa Carica papaya Linn. mengandung alkaloid carpain, nikotin, flavonol, tanin dan terpinena serta enzim seperti papain dan chymopapain $^{[5]}$.

Buah pepaya memiliki kandungan protein, lemak, serat, karbohidrat, mineral, kalsium, zat besi, vitamin $\mathrm{C}$, tiamin, riboflavin, niacin, karoten, asam amino, asam sitrat dan asam malat (buah hijau) dan metabolit sekundersenyawa volatil,alkaloid karpain $^{[9]}$.

Biji pepaya diketahui mengandung lemak, protein, serat, minyak pepaya, karpain, karisin, glukotropakolin, enzimmirosin, glucosinolat, benzil isotiosianat $^{[4,9]}$. 
Daun pepaya yang berwarna hijau, kuning, dan coklat mengandung berbagai senyawa fitokimia, vitamin, dan senyawa asam fenolat, oleh karena itu daun pepaya merupakan sumber potensial makanan dan obat ${ }^{[4,8]}$.

Aktitivitas farmakologi pepaya dari beberapa penelitian sebelumnya menunjukan bahwa ekstrak pepaya dapat menurunkan kadar gula,yang diduga mempunyai kandungan saponin, flavanoid, alkaloid, tanin, steroid, zat fenolat, glikosida dalam ekstrakpepaya. ${ }^{[10]}$.

Artikel ini akan menjelaskan berbagai penelitian tentang aktivitas antihiperglikemik dan hipolipidemik ekstrak biji, daun dan kulit batang tanaman pepaya (Carica papaya Linn.) terhadap tikus yang di induksi aloksan.

\section{Hasil Penelitian}

\section{Ekstrak air}

Pada penelitian ini, diuji ekstrak air biji pepaya dengan dosis $100-400 \mathrm{mg} / \mathrm{kg} /$ BB /hari secara oral selama 30 hari,pada tikus yang diinduksi aloksan. Hasiluji menunjukkan adanya penurunan kadar glukosa darah puasa, trigliserida, kolesterol, LDL, dan VDL sedangkan HDL mengalami peningkatan dibandingkan dengan kelopmpok kontrol yang diberikan glibenklamid $^{[5]}$. Ektrak air biji pepaya ini diketahuiaman, hal ini dibuktikan dengan uji toksisitas pada tikus dengan dosis oral $2000 \mathrm{mg} / \mathrm{kg}$ bahwa ekstrak biji pepaya ini tidak menyebabkan kematian pada tikus ${ }^{[5]}$.

Tabel I. Efek Pemberian Ekstrak Air Biji Pepaya Pada Tikus Setelah 30 Hari

Parameter

$\begin{array}{cc} & \text { I } \\ \text { TG } & 100.5 \pm 1.6 \\ \text { TC } & 100.0 \pm 3.1 \\ \text { HDL } & 23.0 \pm 0.5 \\ \text { LDL } & 56.9 \pm 1.5 \\ \text { VLDL } & 19.1 \pm 0.8\end{array}$

Keterangan :

TG : Trigliserida

TC : Total Kolesterol

HDL : High Density Lipoprotein

LDL : Low Density Lipoprotein

VLDL : Very Low Density Lipoprotein

Kadar Parameter Uji pada Tiap Kelompok Tikus

II III

$82.3 \pm 9.5$

$88.5 \pm 4.4$

$27.2 \pm 1.2$

$51.4 \pm 2.6$

$11.1 \pm 1.8$
$73.7 \pm 4.8$

$81.3 \pm 3.9$

$37.8 \pm 1.8$

$32.1 \pm 3.7$

$14.5 \pm 1.1$

$$
\text { IV }
$$

$68.3 \pm 2.8$

$71.0 \pm 1.0$

$39.0 \pm 2.8$

$19.7 \pm 1.5$

$12.3 \pm 1.4$
V

$50.3 \pm 7.7$

$63.7 \pm 2.3$

$43.0 \pm 0.6$

$11.9 \pm 1.0$

$8.7 \pm 1.8$ 
Penelitian aktivitas antihiperglikemik juga dilakukan terhadap ekstrak air daun pepaya, dengan dosis yang sama dengan ekstrak air biji pepaya, yaitu100$400 \mathrm{mg} / \mathrm{kg} \mathrm{BB}$, secara intra peritonial selama 21 hari. Hasil uji terdapat penurunankadar glukosa darah ${ }^{[8]}$.Hasil analisis fitokimia ekstrak daun pepaya diketahui adanya kandungan tanin, alkaloid, flavanoid, saponin, anthraquinon, antosianosida yang salah satu dari senyawa ini mempunyai aktivitas sebagai antihiperglikemik ${ }^{[3]}$.

Tabel II. Efek Pemberian Ekstrak Air Daun Pepaya Pada Tikus Setelah 21 Hari

Kelompok

Normal

Diabetes

Alloxan

Alloxan+ekstrak 100 mg/kg

Alloxan+ekstrak $200 \mathrm{mg} / \mathrm{kg}$

Alloxan+ekstrak 400 mg/kg

\section{Ekstrak metanol}

Penelitian ekstrak metanol kulit batang pepaya terhadap aktivitas antihiperglikemik dan hipolipidemik telah dilakukan pada tikus dengandosis $500 \mathrm{mg} / \mathrm{kg}$ BB pada tikus selama 30 hari $^{[4]}$. Hasil memperlihatkan menunjukkan adanya penurunan yang signifikan konsentrasi glukosa darah oleh ekstrak metanol kulit batang pepaya ini ${ }^{[10]}$.

\section{Hasil dan Pembahasan}

Berdasarkan review artikel ini ekstrak air biji, daun dan ekstrak metanol kulit batang pepaya dapat memberikan aktivitas penurunan gula darah. Waktu yang di teliti pada review ini adalah selama 21 dan 30 hari pada tikus yang di induksi oleh aloksan. Dosis pada pengujian ini menggunakan kadar ekstrak air pada biji dan daun sebesar 100 - $400 \mathrm{mg} / \mathrm{BB}$ sedangkan dosis pada ekstrak metanol pada kulit batang adalah kadar 500 mg / BB.

Kandugan fitokimia yang bertanggung jawab dalam aktivitas farmakologi ini diduga dari kandungan alkaloid, flavonoid, senyawa polifenolat dan enzim papain yang merupakan kandungan utama dalam ekstrak air dan metanol biji maupun daun pepaya ini.
Hari Ke -

$\begin{array}{ccc}7 & 14 & 21 \\ 88.8 \pm 1.3 & 89.7 \pm 1.9 & 90.4 \pm 1.3 \\ 280 \pm 1.2 & 293 \pm 2.2 & 313.2 \pm 3.6 \\ 165.3 \pm 4.2 & 107.7 \pm 3.2 & 95.5 \pm 1.4 \\ 270.1 \pm 6.1 & 270 \pm 5.2 & 269.3 \pm 4.9 \\ 242.4 \pm 4.8 & 230.7 \pm 5.2 & 221.4 \pm 4.3 \\ 190.4 \pm 9.7 & 170.7 \pm 5.8 & 151.6 \pm 2.6\end{array}$

\section{Kesimpulan}

Dari studi pustaka dapat disimpulkan bahwa ekstrak polar (air dan metanol) biji dan daun pepaya menunjukan aktivitas antihiperglikemik dan hipolipidemik yang signifikan pada tikus diabetes. Pepaya merupakan salah satu tanaman yang potensial untk dikembangkan sebagai tanaman obat alernatif untuk menangani diabetes melitus dan hiperlipidemia. Diperlukan penelitiaan lebih lanjut untuk mengetahui senyawa aktif yang menimbulkan efek tersebut.

\section{Referensi}

[1] S.O. Olabanji, A.C. Adebanjo, O.R. Omobuwajo, D. Ceccato, M.C. Buoso, G. Moschini., 2014,Analysis of some Nigerian anti-diabetic medicinal plants (II), B 318 187-190

[2] F. Raffaelli, L. Naneti, G. Montecchiani, F. Borroni, E. Salvolini, E. Falolia, dkk, 2015, In vitro effect of fermented papaya ( Carica papaya, L) on platelets obtained from patiens with type 2 diabetes, Nutrition, Metabolism \& Cardiovascular Diseases, 25, 224229.

[3] Yasmeen Maniyar, Prabhu Bhixavatimah., 2012, Antihyperglycemic and hypolipidemic activities of aqueous 
exstract of carica papaya Linn. Leaves in alloxan-induced diabetic rats, Journal of Ayurveda \& Integrative Medicine 3, (2)

[4] Isela Esther Juares-Rojop, Juan C Diaz-Zagoya, Jorge L Ble Castillo., 2012, Hypoglycemic effect of Carica papaya leaves in streptozotocininduced diabetic rats, Juares - Rojop et al BMC Complementary and Alternative Medicine, 12:236.

[5] Adeneye, A. A.; Olagunju, J. A., 2009, Preliminary Hypoglycemic and Hypolipidemic Activities of the Aqueous Seed Extract of Carica Papaya Linn. In Wistar Rats. Biology and Medicine, 1 (1), 1-10.

[6] Tandi Herbie., 2015 Kitab Tanaman Berkhasiat Obat 226 tumbuhan obat untuk menyembuhkan penyakit dan kebugaran tubuh, Edisi Pertama, Octopus Publishing House, Yogyakarta

[7] Isela Esther Juares-Rojop, Juan C Diaz-Zagoya, Jorge L Ble Castillo., 2012, Hypoglycemic effect of Carica papaya leaves in streptozotocininduced diabetic rats, Juares - Rojop et al BMC Complementary and Alternative Medicine, 12:236.

[8] Cahya S, Rini Susiana., 2016, Grow Your Own Medical Plant - Panduan Praktis Menanam 51 Tanaman Obat Popular di Pekarangan, Edisi pertama, Lily publisher, Yogyakarta

[9] Vij Tarun, Yash Prashar., 2015 A review on medicinal properties of Carica papaya Linn. Asian PacJournal of Tropical Disease 5(1), 1-6.

[10] Saidu, A. N and Nweri, C. G., 2013,, Phytochemical Screening and Effects of Methanol Extract of Carica papaya stem bark in alloxan induced Diabetic Rats, Journal Of Emergining Trends in Engineering Aplied Sciences 4 (6), 819-822. 